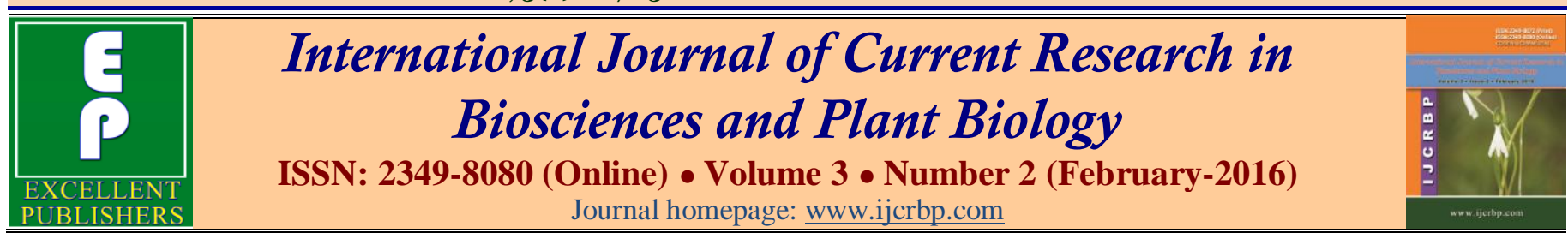

\title{
Diversity and Management of Banana and Plantain (Musa spp.) Varieties in Togo
}

\author{
R. Koukouma', H. Yedomonhan², A. Dansi3* ${ }^{*}$, A. Adjatin ${ }^{3}$ and P. Agre 3 \\ ${ }^{1}$ Institut de Conseil et d'Appui Technique Agricoles, BP: 20804, Lomé-Cacavéli, République du Togo \\ ${ }^{2}$ Laboratoire de Botanique et Ecologie Végétale (LaBEV), Faculté des Sciences et Techniques, Université d'Abomey-Calavi (UAC) \\ ${ }^{3}$ Laboratory of Biotechnology, Genetic Resources, Plant and Animal Breeding (BIORAVE), Faculty of Sciences and Technology of \\ Dassa, Polytechnic University of Abomey, BP 14 Dassa-Zoumè, Benin
}

*Corresponding author.

\begin{abstract}
A bstract
Banana and plantain are important economic and food crops in Togo but neglected by scientific research and development programs. Its production is still marginalized and its diversity is unknown. To assess the varietal diversity of both Banana and plantain at the community level and define strategies for its management, 36 villages and 188 households were selected and surveyed using participatory research appraisal tools (questionnaire) and techniques (focus group discussion, individual survey, field visit). A total of 113 farmer-named varieties were recorded among which 57 banana varieties and 56 plantain varieties. The number of the local varieties found varies from 3 to 12 with an average of 8 per village. The analysis of distribution revealed that on average 3 varieties per village are grown by many households on large area and considered as elite varieties. In the villages where some varieties are threatened, the rate of endangered varieties varies from $16.75 \%$ to $75 \%$ with an average of $40.07 \%$. The principal reasons of diversity loss identified were of agronomic, economic and nutritional nature. Producers' varietal preferences criteria and production constraints were also documented.
\end{abstract}

\section{Article Info}

Accepted: 30 January 2016

Available Online: 06 February 2016

Ke ywords

Banana

Participatory evaluation

Plantain

Togo

Varietal diversity

\section{Introduction}

Banana and plantain are cultivated in over 100 countries in the tropical and subtropical regions of the world where they constitute a major staple food crop for millions of people, as well as providing a valued source of income through local and international trade (Valmayor and Danh, 2002; Bakry et al., 2005; Odah et al., 2013). They are grown over a harvested area of approximately 10 million hectares, with an annual production of around 88 million metric tons (Odah et al., 2013). Banana and plantain are the developing world's fourth most important global food crop after rice, wheat and maize in terms of gross value of production (Lassoudière, 2007). The vast majority of producers are small scale farmers growing the crop either for home consumption or for local markets. As well as being a cheap and easily produced source of energy, they are also rich in vitamins A, C and B6 (Onguso, 2003; Lassoudière, 2007).

Furthermore, with increasing urbanization, bananas and plantains are becoming more and more important as cash crops, in some cases providing the sole source of income to rural populations, thus playing an important role in poverty alleviation. Banana and plantain are one of the cheapest foods to produce (Lassoudière, 2007, Odah et al., 2013) and are 
therefore, important food for low-income families (Odah et al., 2013).

In Togo, Banana and plantain are one of the important food and cash crops and plays a critical role in ensuring food security for many households. They are also a suitable raw material for industrial glucose and syrup production (Odah et al., 2013). Apart from human consumption and industrial use, banana and plantain leaves can also be processed for use as animal feed (Bakry et al., 2005). However, in Togo, little progress has been done on documenting the local varieties of the crops. Hence, the objective of this study was two folds:

- Document the varietal diversity of Banana and plantain and associated indigenous knowledge in Togo.

- Identify the farmers' varietal preference criteria for use in breeding schemes

\section{Materials and methods}

\section{Study area}

The study was conducted in Togo. The country is partitioned into five economics Regions (Savane, Kara, Centrale, Plateaux and Maritime) inhabited by many ethnic groups among which the most important are Ewé, Akposso, Akébou and Ouactchi in south Agnanga-Adélé' and Ifè in the Centre and Moba and Kabyèin the North (Lévéque, 1979). Maritime, Plateaux and Centrale Regions are relatively humid agro-ecological zone with two rainy seasons and a mean annual rainfall varying from $1100 \mathrm{~mm}$ to $1400 \mathrm{~mm} /$ year. The vegetation is of semi-deciduous forests or woodland and savannah woodland (Worou, 2000). Kara and Savane Regions are dried with only one rainy season (Worou, 2000). Mean annual temperatures ranges from $26^{\circ} \mathrm{C}$ to $28^{\circ} \mathrm{C}$ (Brabant et al., 1996). In order to sufficiently cover the study area and based on national production statistics, 36 villages were selected throughout the different regions and surveyed (Fig. 1).

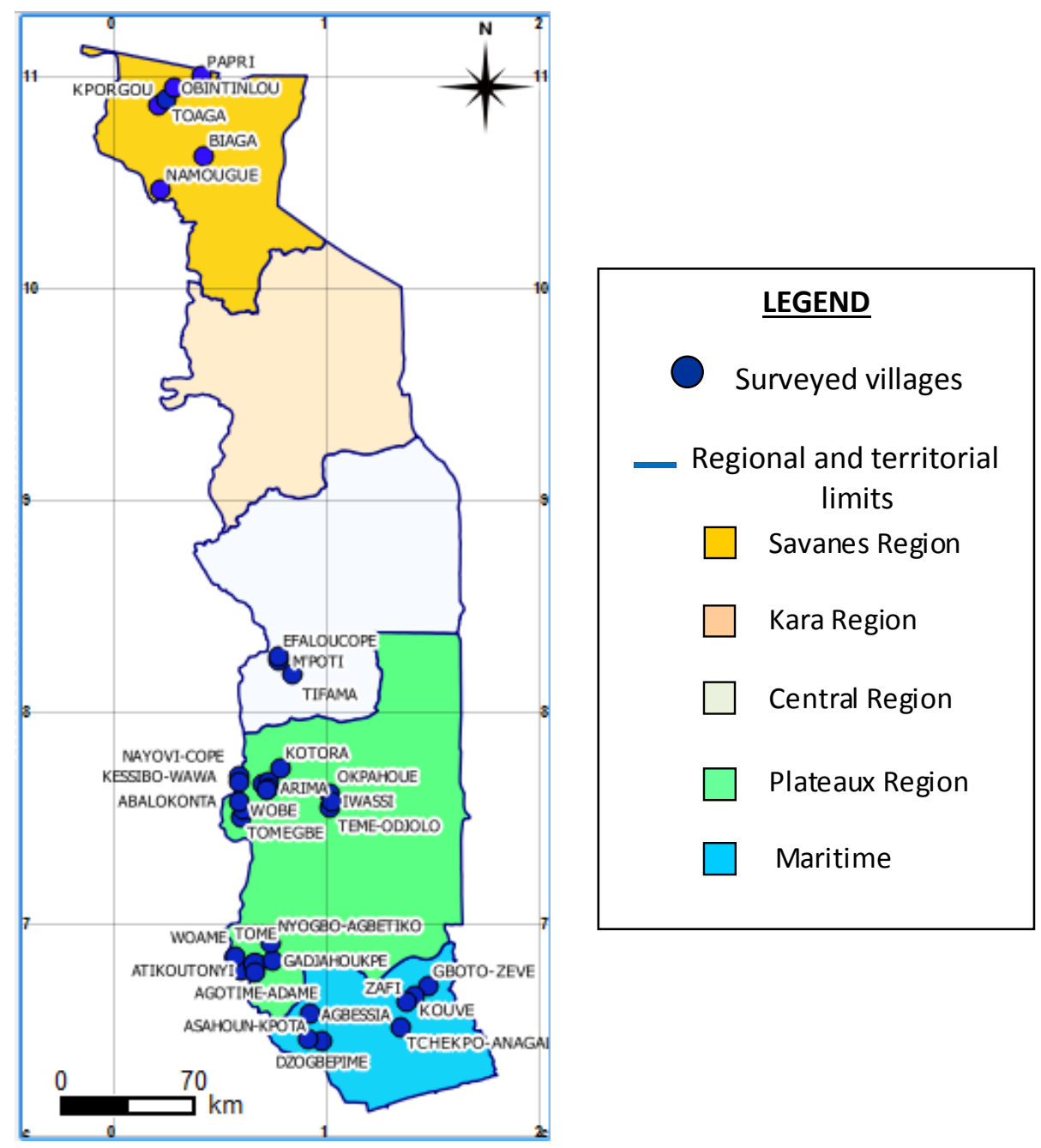

Fig. 1: Map of Togo showing the surveyed villages. 


\section{Data collection}

Data were collected during expeditions to the different sites (36 villages) through application of participatory research appraisal tools and techniques, such as direct observations, group discussions and field visits using questionnaire following Agre et al. (2015). Discussions were conducted with the help of translators from each area. In each site, local farmers' associations were involved in the study to facilitate the organization of the meetings and the collection of data. Farmers were then asked to list (vernacular names) and show, in their home gardens or fields, the different cultivars that they grow in their villages. Through discussions, the detailed agronomic, culinary and technological characteristics of the listed cultivars were documented.

The distribution and extent of the cultivars were assessed using the Four Squares Analysis approach described by Gbaguidi et al. (2013); Agre et al. (2015). The Four Squares Analysis approach help classifying existing varieties into four groups: varieties cultivated by many households on large areas; varieties cultivated by many households on small areas; varieties cultivated by few households on large areas, and varieties cultivated by few households on small areas. Detailed information was collected on each of the varieties with the objective of understanding farmers' knowledge and preferences for specific cultivars.

Taste and pulp texture were assessed following Dadzie and Orchard (1997) using specific values as ' 1 ' when the varieties is perceived as very good performing, ' 2 ' when it is perceived as good, ' 3 ' when acceptable and ' 0 ' if not.

The identified banana and plantain local varieties were in situ characterized in participatory way (with farmers) using qualitative traits among which the fruit color at harvest time following Tomékpé (1996). The morphological traits considered were later used to assess the diversity among and between populations.

\section{Data analysis}

Data was analysed using both descriptive statistics and multivariate analysis. Descriptive statistics (frequency, percentage, mean, etc.) was used to generate summaries and tables at different (villages, departments, study area) levels with Statistica 7.1 software. Shannon-Weaver diversity index was used to assess landrace diversity in the study area. The rates of threatened varieties (RTV) was calculated per village using the formula RTV = $[(\mathrm{n}-\mathrm{k}) / \mathrm{N}] * 100$, where $\mathrm{n}=$ number of varieties cultivated by few households on small areas, $\mathrm{k}=$ number of newly introduced varieties, and $\mathrm{N}=$ total number of cultivars recorded in the village (Kombo et al., 2012; Agre et al., 2015). To understand the morphological variability among the different banana and plantain landraces characterized in situ a binary matrix (Varieties/variables) was developed and a dendrogram constructed with Minitab 14 software.

\section{Results and discussion}

\section{Diversity, distribution, and extent of banana and plantain varieties in Togo}

At total 113 farmer-named banana and plantain varieties (57 banana and 56 plantains) were recorded (Table 1). The lowest diversity was observed in Savannah region and the highest diversity was recorded in some villages located in Plateaux and maritime region (Table 1). An average of 8 banana varieties was recorded per village. Across sociocultural groups, the highest diversity (25 32 varieties) was found with Ewé, Akposso and Akébou. Also the number of the dessert banana is more important than the one of plantain. The number of landraces varied from 2 to 12 (8 on average) per village (Table 1). Villages Okpahoué (Plateaux region), Gboto-Zévé and Zafi (Maritime region) presented the highest diversity.

Despite the availability of existing banana diversity, across the country, on average 3 varieties per village were popular and cultivated by many households. According to farmers surveyed, banana and plantain cultivated by many households on large areas are those that are economically profitable. In the villages, where threatened varieties were reported, the rate of such varieties varied from $16.75 \%$ to $75 \%(40.07 \%$ on average) (Table 1). The highest rate $(75 \%)$ was recorded at Biaga village located in Savannah region and the lowest was found atAtikoutonyi/Louwèand Tomékpé villages all located in Plateaux Region. The rate of threatened varieties (RTV) was high in many villages more than the average value.

The reasons for abandonment of banana and plantain varieties in Togo vary according to the category of plant. With plantain reasons of abandonment were mostly related to poor agronomic performances (84\% of responses). Among these agronomics reasons, susceptibility to lodging and drought, reduction of the productivity with the age and low suckers generation capacity were the most important (Fig. 2). 
Table 1. Diversity, distribution, extent and rate of threatened banana and plantainlandraces in Togo.

\begin{tabular}{|c|c|c|c|c|c|c|c|c|c|c|}
\hline \multirow{2}{*}{ Regions } & \multirow{2}{*}{ Villages } & \multirow{2}{*}{ TNV } & \multirow{2}{*}{ NPV } & \multirow{2}{*}{ NBV } & \multicolumn{4}{|c|}{ Distribution and extent } & \multirow{2}{*}{ NIV } & \multirow{2}{*}{$\begin{array}{l}\text { RTV } \\
(\%)\end{array}$} \\
\hline & & & & & $\mathbf{H}+\mathbf{A}+$ & $\mathbf{H}+\mathbf{A}-$ & H-A+ & H-A- & & \\
\hline \multirow[t]{3}{*}{ Centrale } & Efaloucopé & 10 & 4 & 6 & 3 & 2 & 0 & 5 & 1 & 40.00 \\
\hline & Tifama & 10 & 4 & 6 & 3 & 2 & 0 & 5 & 1 & 40.00 \\
\hline & M'poti & 7 & 3 & 4 & 3 & 2 & 0 & 2 & 0 & 28.57 \\
\hline \multirow[t]{20}{*}{ Plateaux } & Arima & 9 & 5 & 4 & 3 & 2 & 0 & 4 & 0 & 44.44 \\
\hline & Atékpo & 9 & 5 & 4 & 3 & 2 & 0 & 4 & 0 & 44.44 \\
\hline & Agnigbagnon & 10 & 7 & 3 & 3 & 3 & 0 & 4 & 0 & 40.00 \\
\hline & Veh-N'kougna & 11 & 6 & 5 & 3 & 2 & 0 & 6 & 1 & 45.45 \\
\hline & Kotora & 11 & 7 & 4 & 3 & 2 & 0 & 6 & 0 & 54.55 \\
\hline & Woamé & 11 & 5 & 6 & 3 & 2 & 0 & 6 & 1 & 45.45 \\
\hline & Tomé & 11 & 6 & 5 & 3 & 2 & 0 & 6 & 1 & 45.45 \\
\hline & Atikouton & 6 & 3 & 3 & 3 & 2 & 0 & 1 & 0 & 16.67 \\
\hline & Tové-Dzigbé & 6 & 4 & 2 & 3 & 2 & 0 & 1 & 0 & 16.67 \\
\hline & Wobè & 10 & 5 & 5 & 3 & 2 & 0 & 5 & 0 & 50.00 \\
\hline & Abalokonta & 8 & 5 & 3 & 3 & 2 & 0 & 3 & 0 & 37.50 \\
\hline & Johsoncopé & 7 & 4 & 3 & 3 & 2 & 0 & 2 & 0 & 28.57 \\
\hline & Tomékpé & 6 & 4 & 2 & 4 & 1 & 0 & 1 & 0 & 16.67 \\
\hline & Késsibo-Wawa & 9 & 5 & 4 & 3 & 1 & 0 & 5 & 1 & 44.44 \\
\hline & Agotimé-Adamé & 8 & 4 & 4 & 4 & 1 & 0 & 3 & 1 & 25.00 \\
\hline & Nyogbo-Agbétiko & 8 & 4 & 4 & 3 & 2 & 0 & 3 & 0 & 37.50 \\
\hline & Gadjahoukpé & 9 & 4 & 5 & 3 & 2 & 0 & 4 & 1 & 33.33 \\
\hline & Témé-Odjolo & 9 & 4 & 5 & 2 & 4 & 0 & 3 & 0 & 33.33 \\
\hline & Iwassi & 9 & 4 & 5 & 2 & 4 & 0 & 3 & 1 & 22.22 \\
\hline & Okpahoué & 12 & 4 & 8 & 3 & 3 & 0 & 6 & 1 & 41.67 \\
\hline \multirow[t]{6}{*}{ Savanes } & Kporgou & 3 & 1 & 2 & 0 & 1 & 0 & 2 & 0 & 22.22 \\
\hline & Toaga & 3 & 1 & 2 & 0 & 1 & 0 & 2 & 0 & 22.22 \\
\hline & Obintinlou & 3 & 1 & 2 & 0 & 1 & 0 & 2 & 0 & 66.67 \\
\hline & Papri & 3 & 1 & 2 & 0 & 1 & 0 & 2 & 0 & 66.67 \\
\hline & Namougue & 7 & 3 & 4 & 0 & 2 & 0 & 5 & 0 & 71.43 \\
\hline & Biaga & 4 & 1 & 3 & 0 & 1 & 0 & 3 & 0 & 75.00 \\
\hline \multirow[t]{7}{*}{ Maritime } & Gboto-Zévé & 12 & 6 & 6 & 3 & 2 & 0 & 7 & 2 & 41.67 \\
\hline & Kouvé & 10 & 5 & 5 & 3 & 1 & 0 & 6 & 2 & 40.00 \\
\hline & Zafi & 12 & 7 & 5 & 3 & 1 & 0 & 8 & 3 & 41.67 \\
\hline & Tchékpo-Anagali & 6 & 3 & 3 & 3 & 1 & 0 & 2 & 0 & 33.33 \\
\hline & Dzogbépimé & 11 & 5 & 6 & 4 & 3 & 0 & 4 & 1 & 27.27 \\
\hline & Assahoun-kpotamé & 8 & 3 & 5 & 3 & 2 & 0 & 3 & 1 & 25.00 \\
\hline & Agbéssia & 9 & 5 & 4 & 2 & 3 & 0 & 4 & 0 & 44.44 \\
\hline Mean & & 8 & 4 & 4 & 3 & 2 & 0 & 4 & 1 & 40,07 \\
\hline
\end{tabular}

NB: TNV: Total number of varieties; NPV: number of Plantain varieties, NBV: Number of Banana varieties; H+A+: varieties cultivated by many households on large areas; H+A-:varieties cultivated by many households on small areas; $\mathrm{H}-\mathrm{A}+$ : varieties cultivated by few households on large areas; H-A-:varieties cultivated by few households on small areas; NIC: newly introduced varieties; NTV: number of disappeared cultivars and RTV: rate of threatened varieties.

Organolectic and economic reasons were also cited. With banana varieties, reasons recorded were also mostly agronomic (62\% of responses)among which invading production of suckers (28\% of responses), low post harvest storage aptitude of the fruits (15\% of responses), low productivity (5\% of responses) and susceptibility to lodging (5\% of responses) (Fig. 3).

Our findings revealed that banana diversity varied across regions. The low diversity at village level in Savannahs region could be explained by the unfavorable agroecological conditions (extreme climatic conditions with low rainfall, poor soils). In this region, banana and plantain are mainly cultivated in lowland and along riversides. The high varietal richness recorded in Ewé, Akposso and Akétou ethnic groups is likely due to favorable banana growing conditions (appropriate rainfall and temperature) (Odah et al., 2013). The average diversity of 8 varieties per village is low compared to the one of yam averaging 27 varieties (Dansi et al., 2011). In 
addition, the average rate $(40.07 \%)$ of threatened varieties per village is higher than the value of $37.01 \%$ obtained for yam in Togo (Dansi et al., 2011). Based on the results obtained, it is important to develop strategies for sustainable conservation of banana and plantain genetic resources in Togo.

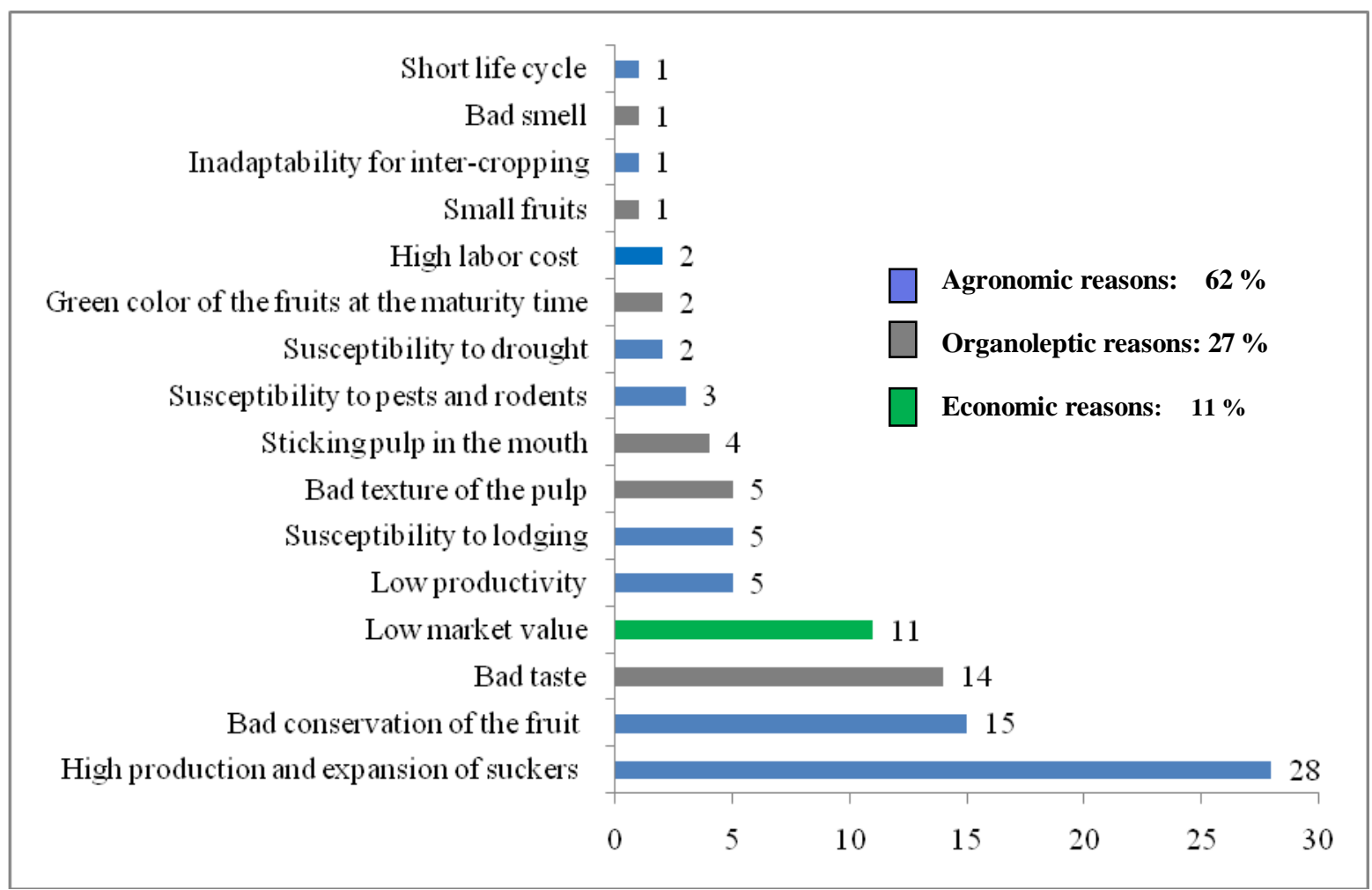

Fig. 2: Reasons for plantain cultivars loss.

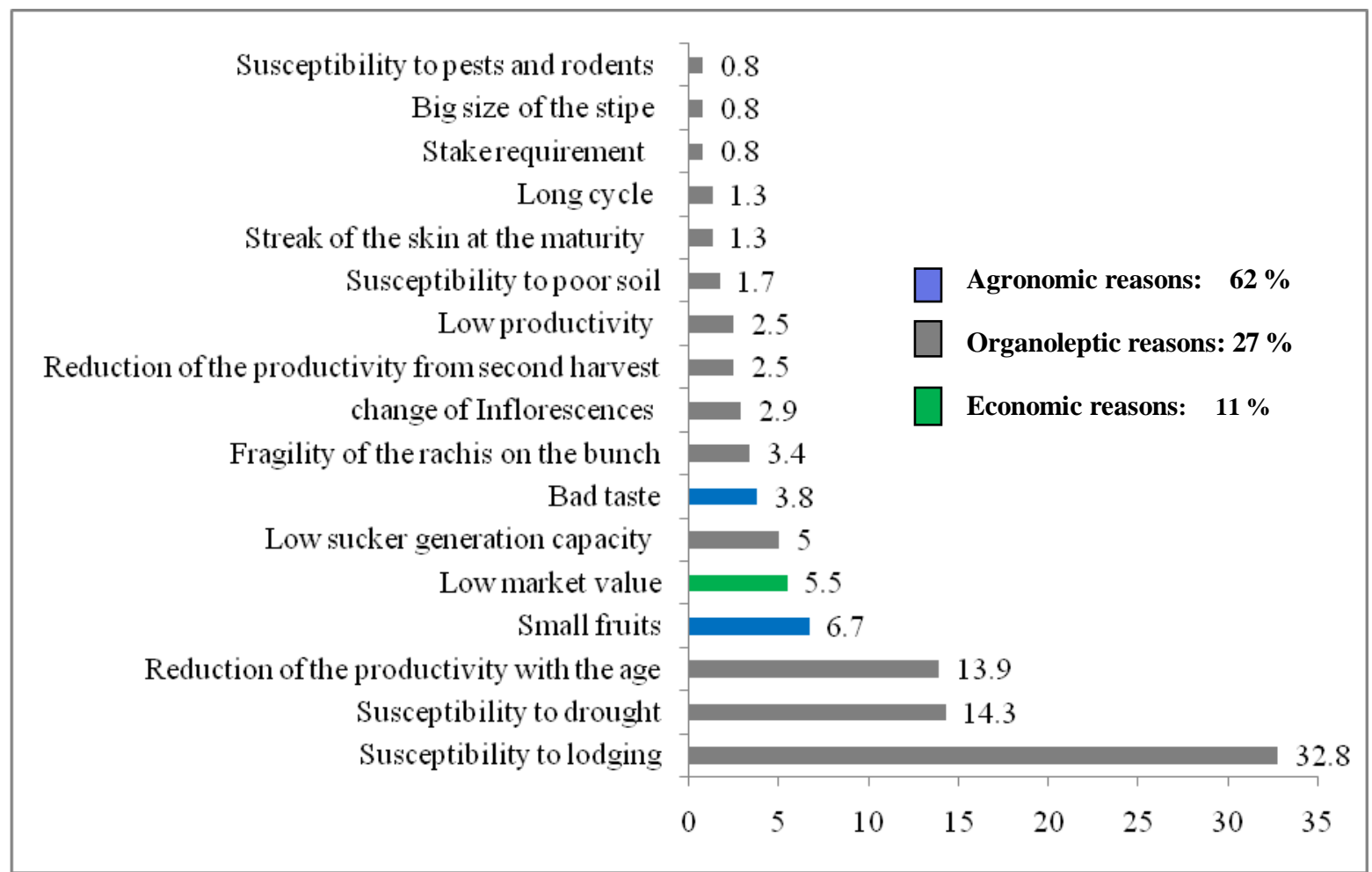

Fig. 3: Reasons for banana cultivars loss. 


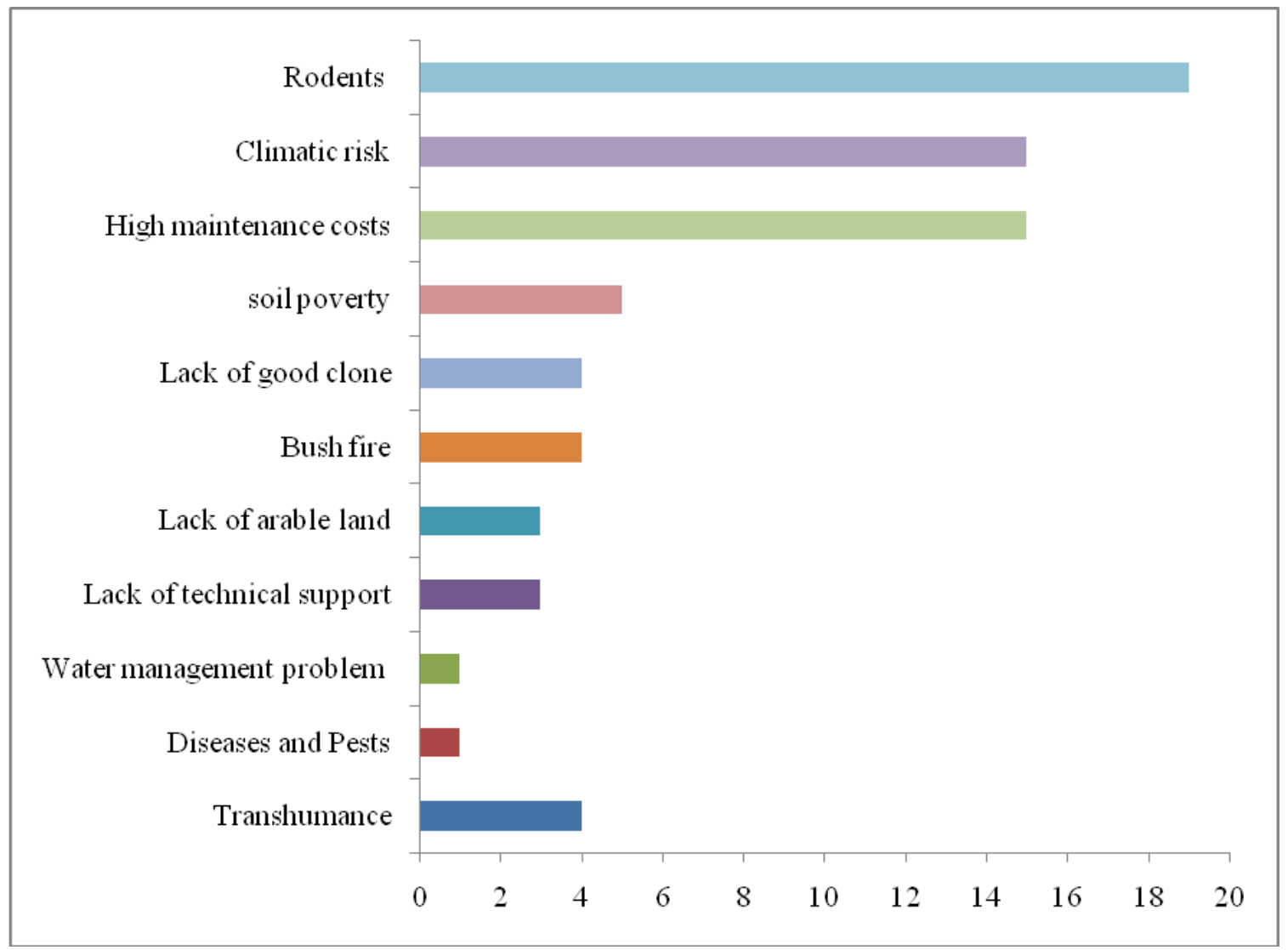

Fig. 4: Banana production constraints in Togo.

It was difficult to reliably assess the varietal distribution and extent across the study areas because of the plurality and variability of the vernacular names given to landraces from one ethnic group to another or from a region to another (Agre et al., 2015). The intra varietal variation observed showed that further studies are necessary to clarify any doubt about the differences among varieties. Thus, sound agro-morphological studies combined with molecular analysis are required to confirm the clustering of bananas varieties ( 3 groups in banana and 4 groups in plantain) obtained based on the morphological variability analysis. Several authors Onguso (2003), Sheela and Gopalan (2006), Lahbib et al. (2012) advocated the use of more precise and complete agro-morphological characterization using IPGRIINIBAP (1996) descriptors to support in situ characterization.

\section{Factors affecting banana and plantain production in Togo}

Based on farmer's responses and perception, thirteen biotic and abiotic production constraints were reported on banana and plantain as main causes for the decline of banana and plantain genetic resources. The most important constraints were susceptible to lodging (28\% of responses), rodents (19\% of responses) and the effects of climate change (15\% of responses) (Fig. 4). Cracking of banana skin as reported is likely physiological (Dadzie and Orchard, 1997) and varieties with thin skins were particularly susceptibles. Consequently, the quality and the market value of the fruits are reduced. Low productivity of varieties such as Kodou-moine, Egouanakodou, Kodou-moangue, Yolodia and Kokoè characterized by short and small fruits are important reasons explaining their abandonment. Mbabwine et al. (2008), Vernier and Dossou (2002) and Baco et al. (2004) highlighted the importance of productivity as factor of preserving varieties by indicating that the introduction of a high yielding varieties led to the abandonment of landraces. Similar results were also observed in pepper (Orobiyi et al., 2012), sorghum (Dossou-Amino et al., 2014) and cassava (Agre et al., 2015).

\section{Farmers' cultivars preference criteria}

In the study area, eighteen (18) farmers' variety preference criteria were recorded among which fifteen (15) were related to banana and seventeen (17) to 
plantain (Table 2). Among the different criteria related to banana, the most important were good taste of the pulp, high productivity (big bunch with many fruits) high market value and good post-harvest storage aptitude of the fruits (Table 2).

Among these criteria recorded for plantain, high market value (32.85\% of responses), high productivity $(22.09 \%$ of responses), good taste (7.51\% of responses), earliness (5.49\% of responses) and good shape of the fruits $(4.60 \%)$ were cited as the most important preference criteria. These criteria vary across the country throughout the ethnic group (Table 3). For the Moba ethnic group for instance located in the Savannah region, the most import criteria were the earliness and drought tolerance accounting respectively for $13 \%$ and $11 \%$ of responses.

Table 2. Farmers' preference criteria of Banana and plantain varieties in Togo.

\begin{tabular}{lll}
\hline Farmers' preference criteria & Study area (\%) & \\
\cline { 2 - 3 } & Banana & Plantain \\
\hline Good taste & 24.64 & 7.58 \\
High productivity & 21.60 & 22.16 \\
High market value & 18.20 & 32.84 \\
Good post-harvest storage & 11.80 & 1.01 \\
Good texture & 3.70 & 0.22 \\
Good shape of the fruits & 3.50 & 4.6 \\
Tolerance to drought & 3.40 & 0.78 \\
Stability of Productivity with the age & 3.30 & 1.23 \\
Earliness & 2.50 & 5.49 \\
Suitability for many foods & 1.60 & 18.5 \\
High nutritive value & 1.70 & 0.11 \\
Resistance to pests, diseases and rodents & 1.30 & 0.22 \\
Good therapeutic and medicinal value & 0.98 & 1.23 \\
Tolerance to weeds & 0.90 & 0.11 \\
Adaptability to poor soils & 0.88 & - \\
Tolerance to lodging & - & 3.14 \\
Suitability to intercropping & - & 0.11 \\
High capacity of suckers development & - & 0.67 \\
\hline
\end{tabular}

Table 3: Importance of farmers' preference criteria across ethnic groups.

\begin{tabular}{|c|c|c|c|c|c|c|c|c|c|c|c|c|}
\hline \multirow{3}{*}{ Farmers' preference criteria } & \multicolumn{12}{|c|}{ Ethnic groups (\% of responses) } \\
\hline & \multicolumn{2}{|c|}{ Agnanga } & \multicolumn{2}{|c|}{ Akébou } & \multicolumn{2}{|l|}{ Ewé } & \multicolumn{2}{|c|}{ Akposso } & \multicolumn{2}{|l|}{ Moba } & \multicolumn{2}{|c|}{ Ouatchi } \\
\hline & B & $\mathbf{P}$ & B & $\mathbf{P}$ & B & $\mathbf{P}$ & B & $\mathbf{P}$ & B & $\mathbf{P}$ & B & $\mathbf{P}$ \\
\hline Good taste & 13.50 & 3.50 & 22.25 & 5.20 & 23.10 & 7.41 & 31.12 & 12.74 & 14.10 & 10.10 & 34.74 & 36.71 \\
\hline High productivity & 12.11 & 19.50 & 24.50 & 21.40 & 17.70 & 16.12 & 14.12 & 22.20 & 21.12 & 19.12 & 28.11 & 29.14 \\
\hline High market value & 30.09 & 44.20 & 21.75 & 33.12 & 17.10 & 31.42 & 18.11 & 28.42 & 14.10 & 24.41 & 14.78 & 13.12 \\
\hline Good post-harvest storage & 18.01 & 4.30 & 4.50 & - & 12.24 & - & 15.10 & - & 6.20 & 4.40 & - & 7.14 \\
\hline Good texture & 7.12 & - & 4.50 & 12.12 & 6.11 & 4.48 & 3.12 & 3.74 & - & - & - & 1.78 \\
\hline Good shape of the fruits & - & 1.20 & 3.50 & 2.20 & 8.20 & 9.21 & - & 4.07 & 4.12 & 14.10 & 6.72 & 1.78 \\
\hline Tolerance to drought & 4.02 & - & 1.25 & 2.10 & 4.49 & 5.11 & - & 4.41 & 11.10 & 4.49 & - & - \\
\hline Stability of productivity with the age & 4.02 & 1.10 & 6.75 & 0.94 & 0.89 & 2.12 & 3.10 & 2.70 & - & 5.01 & 3.10 & - \\
\hline Earliness & - & 3.12 & - & - & 0.89 & 2.12 & - & - & 13.10 & - & - & 2.22 \\
\hline Suitability for many foods & 4.01 & 21.18 & 3.25 & 20.11 & 0.89 & 12.20 & - & - & - & 14.10 & - & \\
\hline High nutritive value & - & - & 1.24 & - & 0.42 & 1.78 & 4.12 & - & - & - & 3.12 & 2.22 \\
\hline Resistance to disease & 4.01 & - & 1.50 & 0.78 & 0.41 & - & 1.10 & - & 3.74 & - & - & 1.01 \\
\hline Cultural value & - & - & - & - & 0.24 & 0.79 & 1.10 & - & - & - & 6.49 & - \\
\hline Tolerance to weeds & - & 2.20 & 4.40 & - & 0.41 & 0.82 & - & - & - & - & - & - \\
\hline Therapeutic and medicinal values & - & - & 1.78 & - & 0.41 & - & 1.10 & - & - & - & - & - \\
\hline Adaptability to poor soils & 3.11 & - & - & - & - & - & 0.84 & - & 6.17 & - & - & - \\
\hline
\end{tabular}




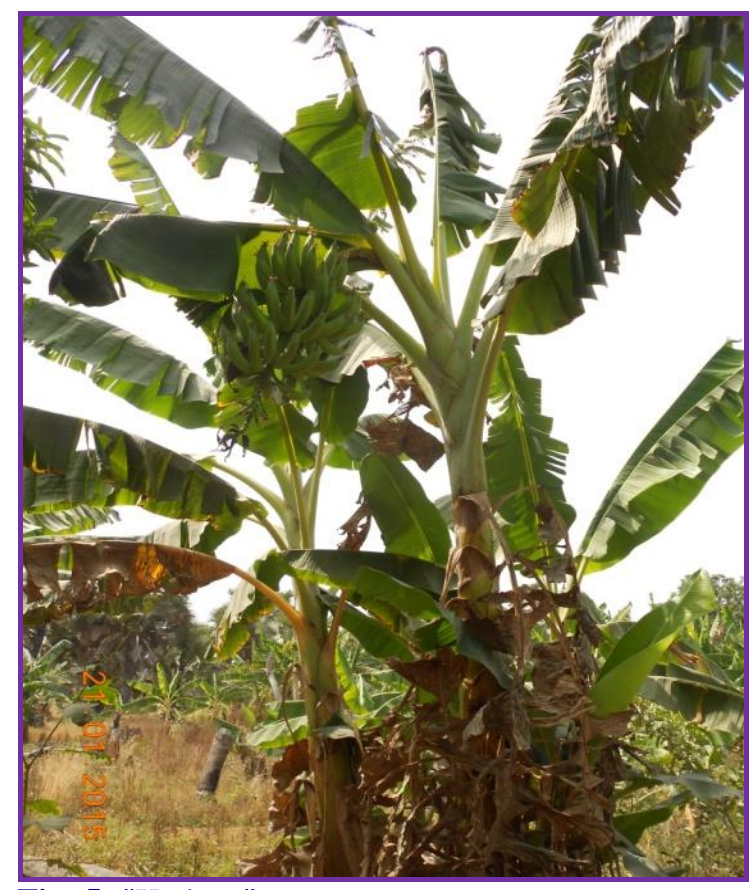

Fig. 5: "Kadaga", green type

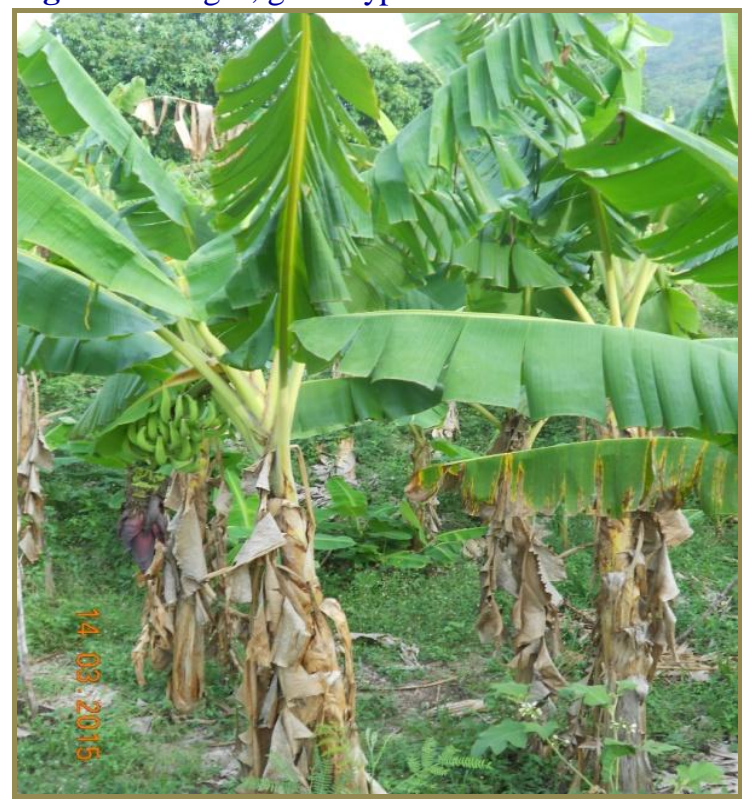

Fig. 7: Apim: "small"

The farmers' variety preference criteria indicated that farmers were more concerned about the organoleptic (good taste) of the banana fruits, which are consumed fresh without processing. High productivity and market value as farmers' preference criteria for both banana and plantain could were expected. High market value resulted from other criteria such as good taste, good post-harvest storage and the suitability for cooking various meals.

In plantain, the importance granted to the resistance of the detachment of the fruits from the bunch was due to

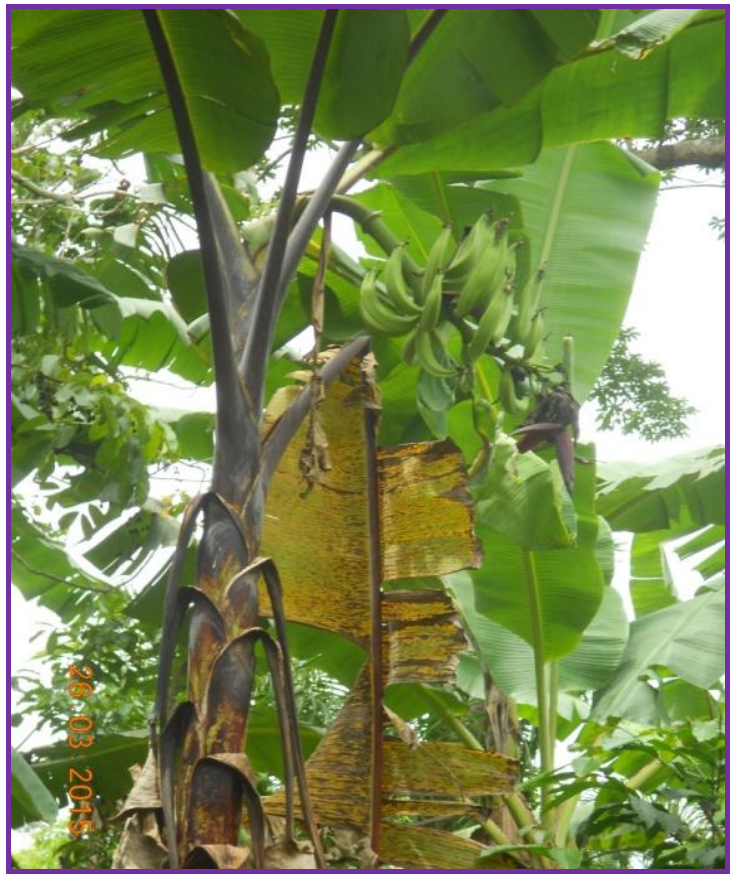

Fig. 6: "Kadaga" purple brown type

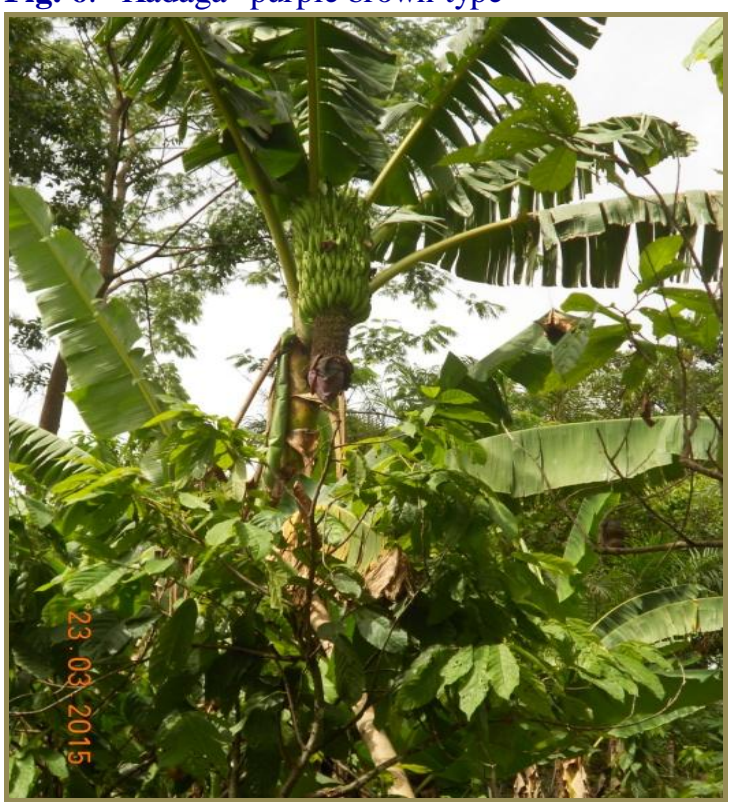

Fig. 8: Apim: "big"

the fact that fruits of some varieties easily detached during post-harvest handlings hence reducing the shelf life of the products and the market value and causing important loss.

Breeding for dwarf varieties could be an option for resistance to bananas lodging. A dwarf variety has better resistance to lodging. Lodging was the major constraint $(28 \%)$ and was consistent with the desire for developing dwarf varieties. It caused serious damage in plantations and required additional labor such as staking. Gold and 
Messiaen (2000) showed that apart from wind squall, storm, hurricane, banana and plantain have redoubtable pests such as black weevils Cosmopolites sordidus which lay eggs in bulb which develop larva that create galleries weakening the bulbs that fall with blowing wind. Resistance to pests causing yield loss, is also an important trait. Lassoudière (2011) found that besides yield loss, pests limit production of a variety or species in a given region. In banana and plantain, lodging and pests are two main constraints that should be addressed by agricultural research in Togo. Effects of climate variability such as erratic rainfall were also reported as major constraints in banana and plantain production. Thus, good agroforestry practices and use of drought resistant or tolerant varieties are valuable strategies to ensure sustainable production. Concerning soil infertility, integrated soil management strategies should be promoted.

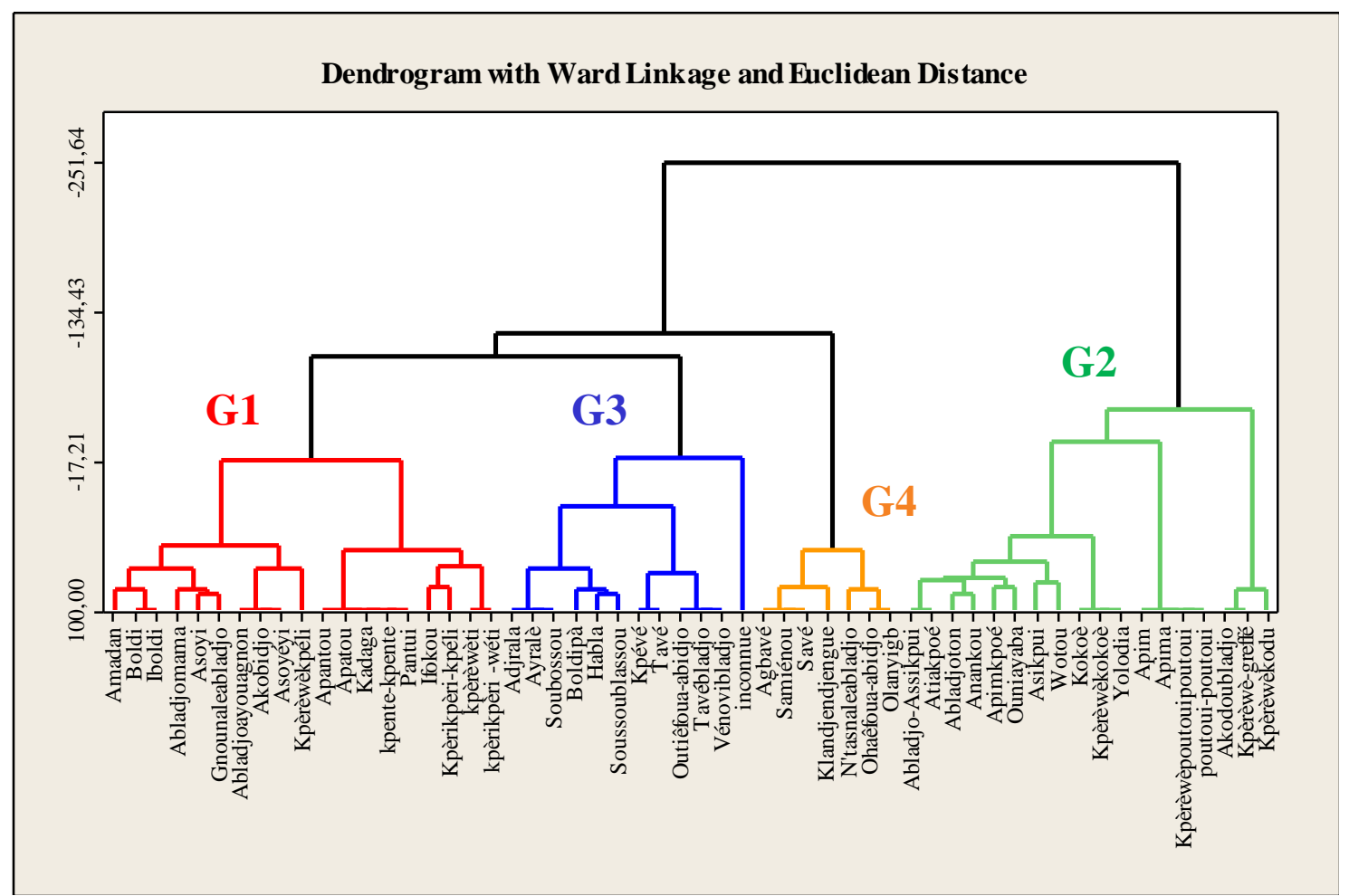

Fig. 9: Dendrogram of plantain varieties based on morphological traits.

\section{Participatory in situ characterization}

Intra-varietal morphological variation (stipe color, size of the bunch) were used to assess the variability. These variations were noted for example with variety Kadaga (brown and green) (Fig. 5 and Fig. 6) and variety Apim (Big and small) (Fig. 7 and Fig. 8). The different descriptors used by farmers allow the classification of the different banana and plantain varieties into subgroups.

Four clusters (G1 to G4; Fig. 9) were generated based on the different morphological traits used by farmers to recognize and to characterize the different plantains varieties:

- G1grouped 19 cultivars characterized by brown green stipe (pseudostem) and long and large fruits.
- G2 contained 18 varieties with high suckers production capacity.G3 have 12 varieties characterized by the presence of incomplete inflorescences and the presence of two bunches with long and large fruits.

- G4 have 7 cultivars with the same characteristic of group 3 except the rightness of the bunches.

Contrarily to plantain, banana varieties were grouped into 3 major clusters ( $\mathrm{C} 1$ to $\mathrm{C} 3)$ based on the in situ evaluation (Fig. 10).

- $\quad$ C1 is composed of 29 banana varieties which are all characterized by the big size of the stipe and average sized bunch.

- $\quad$ C2 has 18 banana varieties with small fruits.

- $\quad$ C3 is characterized by plants of small size. 
The results of this participatory morphological classification indicated the existence of diversity within banana and plantain in Togo and this could be useful for research and development program. Similar results were found in yam (Loko et al., 2013), leafy vegetables (Adjatin et al., 2013) and sorghum (Dossou-Aminon et al., 2014).

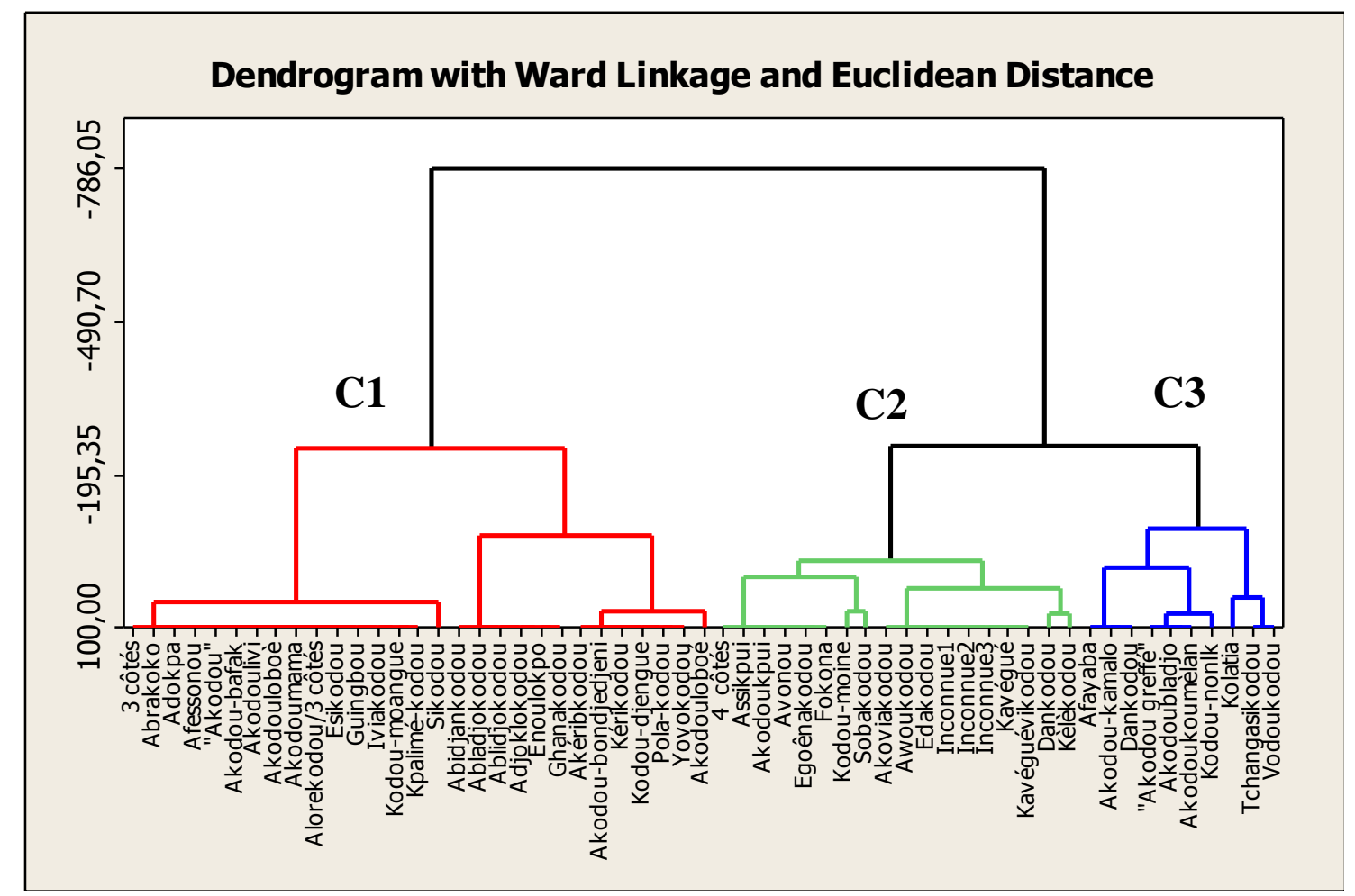

Fig. 10: Dendrogram of banana varieties based on morphological traits.

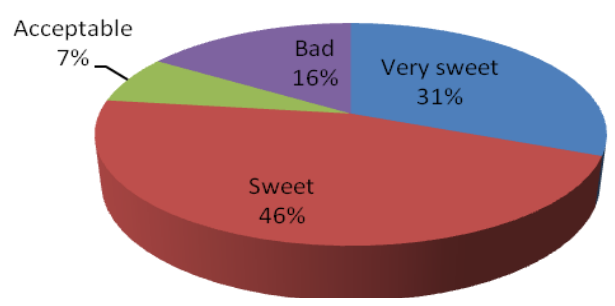

Taste

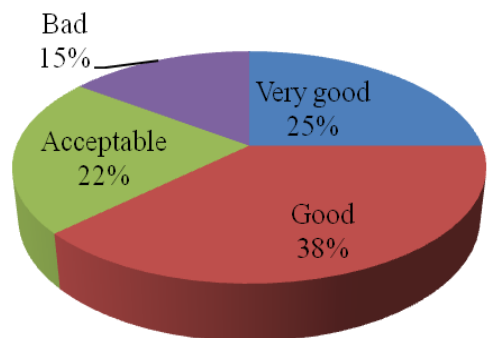

Texture

Fig. 11: Participatory evaluation of banana varieties.

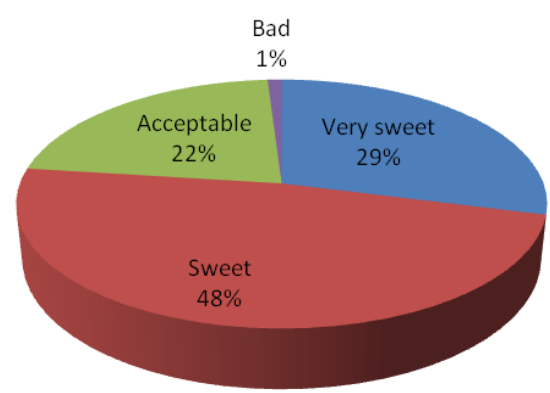

Taste

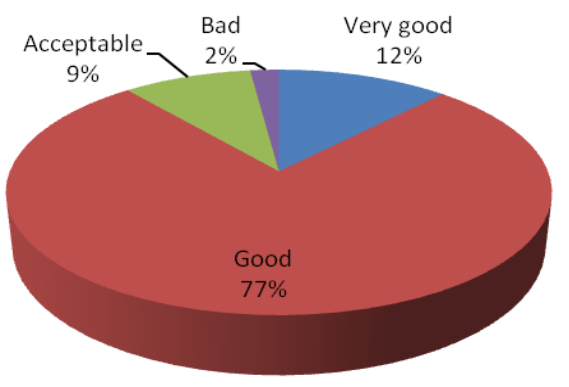

Texture

Fig. 12: Participatory evaluation of Plantain varieties. 


\section{Evaluation of organoleptic characteristics}

Subject to synonymy and among the 113 farmer-named banana and plantain varieties recorded and evaluated through participatory approach,76 \%were reported to have a very good and good taste while $63 \%$ have very good or good texture (Fig. 11 and Fig. 12). Evaluation of organoleptic qualities (taste, texture) revealed that improvement of banana fruits is important since most of the existing varieties are less preferred. Dadzie and Orchard (1997) reported that taste and texture were the most important traits for varietal improvement in banana. For plantain, findings revealed no major issues related to texture and taste. Their good texture allows them to be widely adapted to several meals (boiling, frying, etc.).

\section{Conclusion}

There is a not negligible diversity of banana and plantain landraces in Togo but this is threatened. Preference traits and identified constraints should be taken into account in participatory breeding and varietal exchanges programs. There is then a need to identify among the existing banana and plantain germplasm, varieties that meet farmers and consumers preferences in terms of agronomic, nutritive and organoleptic quality and high economic value. Also, to preserve its diversity due to the high rate of the variety loss, in situ and ex situ conservation should be undertaken.

\section{Conflict of interest statement}

Authors declare that they have no conflict of interest.

\section{References}

Adjatin, A., Dansi, A., Badoussi, E., Loko, Y.L., Dansi, M., Azokpota, P., Gbaguidi, F., Ahissou, H., Akoègninou, A., Akpagan, K., Sanni, A., 2013. Phytochemical screening and toxicity studies of Crassocephalum rubens (Juss. ex Jacq.) S. Moore and Crassocephalum crepidioides (Benth.) S. Moore consumed as vegetable in Benin. J. Curr. Microbiol. Appl. Sci. 2(8), 1-13.

Agre, A.P., Bhattacharjee, R., Dansi, A., Becerra LopezLavalle, L.A., Dansi, M., Sanni, A., 2015. Assessment of cassava diversity, loss of landraces and farmers preference criteria in Southern Benin using farmers' participatory approach. Genetic Resour. Crop Evol. DOI: 10.1007/ s10722-015-0352-1.

Baco M.N., Tostain S., Mongbo R. L., Dainou O., Agbangla C. (2004). Gestion dynamique de la diversité variétale des ignames cultivées (Dioscorea cayenensis - D. rotundata) dans la commune de Sinendé au nord Bénin. Plant Genetic Resour. Newslet. 139, 18-24.
Bakry, F., Carreel, F., Horry, J.P., Jenny, C., Tomékpé, K., 2005. La diversité génétique des bananiers cultivés : situation actuelle et perspectives. Le Sélectionneur Français. (55), 33-41.

Brabant, P., Darracq, S., Egue, K., Simmonneaux, V., 1996. Togo: Etat de dégradation des terres résultant des activités humaines (Notice explicative de la carte), ORSTOM, Paris. 57p.

Dadzie, B.K., Orchard, J.E., 1997. Évaluation post-récolte des hybrides de bananiers et bananiers plantain: critères et méthodes. Guides techniques INIBAP 2. Institut international des ressources phytogénétiques, Rome, Italie; Réseau international pour l'amélioration de la banane et du plantain, Montpellier, France ; Centre technique de coopération agricole et rurale (ACP-UE), Wageningen, Pays-Bas. 77p.

Dansi, A., Dantsey-Barry, H., Agré, A. P., Dossou-Aminon, I., Assogba, P., Loko, Y. L., N'Kpenu, E. K., Kombaté, K., Vodouhè, R., 2013. Production constraints and farmers' cultivar preference criteria for cultivated yams (Dioscorea cayenensis-D. rotundata) in Togo. Int. J. Appl. Biol. Pharmaceut. Technol. 4(2), 191-199.

Dansi, A., 2011. Collecting vegetatively propagated crops (especially roots and tubers). In: Collecting Plant Genetic Diversity: Technical Guidelines - 2011 Update (Eds.: Guarino, L., Ramanatha Rao, V., Goldberg, E.). Bioversity International, Rome, Italy.

Dossou-Aminon, I., Loko, Y. L., Adjatin, A., Dansi, A., Elangovan, M., Chaudhary, P., Vodouhè, R., Sanni, A., 2014. Diversity, genetic erosion and farmer's preference of sorghum varieties [Sorghum bicolor (L.) Moench] growing in North-eastern Benin. Int. J. Curr. Microbiol. Appl. Sci. 3(10), 531-552.

Gbaguidi, A.A., Dansi, A., Loko, L.Y., Dansi, M., Sanni, A., 2013. Diversity and agronomic performances of the cowpea (Vigna unguiculata Walp.) landraces in Southern Benin. Int. Res. J. Agric. Sci. Soil Sci. 3(4), 121-133.

Gold, C.S., Messiaen, S., 2000. The banana weevil, Cosmopolites sordidus. Musa Pest Fact Sheet No. 4. INIBAP, France.

IPGRI-INIBAP, 1996. Les descripteurs pour le bananier (Musa ssp.). $59 \mathrm{p}$.

Kombo, G.R., Dansi, A., Loko, L.Y., Orkwor, G.C., Vodouhè, R., Assogba, P., Magema, J.M., 2012. Diversity of cassava (Manihot esculenta Crantz) cultivars and its management in the department of Bouenza in the Republic of Congo. Genetic Resour. Crop Evol. 59(8), 1789-1803.

Lahbib, K., Bnejdi, F., Gazzah, M., 2012. Genetic diversity evaluation of pepper (Capsicum annuиm L) in Tunisia based on morphological characters. Afr. J. Agric. Res. 7(23), 3413-3417.

Lassoudière, A., 2007. Le bananier et sa culture. Quaeversailles. 5(2), 1-383.

Loko, Y. L., Dansi, A., Linsoussi, C., Assogba, P., Dansi, M., Vodouhè, R., Akoegninou, A., Sanni, A., 2013. Current status and spatial analysis of Guinea yam (Dioscorea cayenensis Lam. - D. rotundata Poir. complex) diversity in Benin. Int. Res. J. Agric. Sci. Soil Sci. 3(7), 219-238. 
Mbabwine, Y., Sabiiti, E., Kiambi, N., Mulumba, J.W., 2008. Erosion génétique écogéographique, gestion des semences et conservation des ressources phytogénétiques dans les hautes terres de Kabale, Ouganda. FAO Biodiversity, Bulletin des ressources phytogénétiques $n^{\circ} 156,33-41$.

Odah, K., Aziadekey, M., Tozo, K., Akpavi, S., Koukouma, R., Guelly, A., Kokou, K., Assignon, K., Akogo, Y., Aidam, A., Akpagana, K., Kenny, L., Ait-Oubahou, A., Zinsou, C., Gbéassor, M., 2013. La diversité génétique des bananiers plantains cultivés dans la zone Ouest de la Région des Plateaux au Togo. http://ajol.info/index.php lijbcs.

Onguso, J. M., 2003. Caractérisation génétique de Musa spp. au Kenya. M. Sc. Thèse soumise à l'Université Kényatta, Nairobi, Kenya. Mus Africa. 1(1), 9-15.

Orobiyi, A., Dansi, A., Assogba, P., Loko, L. Y., Dansi, M., Vodouhè, R., Akoègninou, A., Sanni, A., 2012. Chili (Capsicum annuum L.) in southern Benin: production constraints, varietal diversity, preference criteria and participatory evaluation. Int. Res. J. Agric. Sci. Soil Sci. 3(4), 107-120.
Sheela, M.S., Gopalan, A., 2006. Association studies for yield and its related traits of fodder cowpea in F4 generation. J. Appl. Sci. Res. 2(9), 584-586.

Tomekpe, K., 1996. Caractérisation des Bananiers dans Recherches sur la gestion des cultures de bananes et de bananes plantain. Stage régional de formation, CRBP/ IITA. pp.17-29.

Valmayor, R. H., Le Dinh Danh., 2002. Classification et caractérisation de Musella splendida sp. Nov. InfoMusa. 11(2), 24-27.

Vernier, P., Dossou, R. A., 2002. Adaptation of yam (Dioscorea spp) cultivation to changing environment and economic constraints in Benin, Africa. Proceeding of the 12th Symposium of ISTRC on Potential of Root Crops for Food and Industrial Resources, Tsukuba, Japan, 1016/09/2000, ISTRC.

Worou S. K. (2000). Sols dominants du Togo - corrélation avec la Base de référence mondiale. In FAO Rôme-Italie 2000. Cachier d'agriculture.

\section{How to cite this article:}

Koukouma, R., Yedomonhan, H., Dansi, A., Adjatin, A., Agre, P., 2016. Diversity and management of banana and plantain (Musa spp.) varieties in Togo. Int. J. Curr. Res. Biosci. Plant Biol. 3(2), 127-138. doi: http://dx.doi.org/10.20546/ijcrbp.2016.302.016 